\title{
Knowing urban informalities
}

\section{Colin Marx}

Urban Studies

2019, Vol. 56(3) 494-509

(C) Urban Studies Journal Limited 2018

Article reuse guidelines:

sagepub.com/journals-permissions

DOI: $10.1177 / 0042098018770848$

journals.sagepub.com/home/usj

The Bartlett Development Planning Unit, University College London, UK

\section{Emily Kelling}

Sociology of Planning and Architecture, Institute of Sociology, Technische Universität Berlin,

Germany

\begin{abstract}
How do Anglophone urban scholars know urban informalities? This article reviews three dominant ways of knowing urban informality, noting that, despite the profoundly rich insights they each provide, two critiques of the overall concept endure. These are that the concept is often imprecise, and that the contribution to knowing 'the urban' more generally remains clearly circumscribed to the 'urban non-west'. In our view, these limitations curtail the possibilities of sharpening our understanding of the relationship to inequalities and injustices. We work with these critiques, suggesting that they represent two sides of the same problem, associated with binaries. In doing so, we build on the existing emphasis on practices and work across the three dominant ways of knowing urban informalities. This reveals that binaries are not held together magically and transparently so that each is the mirror opposite. Instead, the difference is constituted through unnamed aspects of common denominators - two of which we highlight (property rights and aesthetics) - and may be intrinsic to the way urban informality has come to develop. It is through the latent power relations that inhere in these common denominators that urban scholars can achieve greater conceptual precision and make different contributions to broader urban theory committed to challenging injustices.
\end{abstract}

\section{Keywords}

development, planning, poverty/exclusion, theory, urban informality, urban theory

\section{Corresponding author:}

Colin Marx, The Bartlett Development Planning Unit, University College London, 34 Tavistock Square, London, WCIH 9EZ, UK.

Email: c.marx@ucl.ac.uk 


\section{摘要}

英语世界的城市学者如何看待城市非正规性? 本文回顾看待城市非正规性的三种主要方式, 并指出, 尽管它们都提供了深刻而丰富的见解, 但对这一整体概念的两点评论经久不衰。 这两点评论就是：这个概念常常不准确，而且更普遍地认识“城市”的贡献显然局限于“非西 方城市”。我们认为, 在加深我们对不正规性与不平等和不公平之间的关系的理解方面, 这 些限制减少了可能性。我们研究这两点评论, 表明它们代表了同一问题的两个方面, 与二 重性相关。在此过程中，我们发扬了看待城市非正规性的三种主要方式对实践和工作的既 有强调。这表明二重性没有被神奇而透明地结合在一起，以至于每一个方面都镜像另一个 方面。相反, 差异通过一些未被提及的共性方面被构建（其中我们强调的两个方面是产权 和美学），并且可能是城市非正规性发展方式的固有特征。正是通过这些共性中固有的权 力关系, 城市学者才能达到更高的概念精确度, 并对致力于挑战不公正的、更广泛的城市 理论做出不同的贡献。

\section{关键词}

发展、规划、贫穷/排斥、理论、城市非正规性、城市理论

Received 2017; accepted 2018

\section{Introduction}

This article improves the effectiveness of the concept of urban informality to analyse urban dynamics and challenge injustices. We are clearly not alone in this endeavour. Others have focused on informality as the 'negotiability of value' (Roy and AlSayyad, 2004), 'assemblages' (Dovey, 2012; McFarlane, 2012), 'interfaces' (Schindler, 2014, 2017) and the 'relational' (Boudreau and Davis, 2017) to afford key insights into the creation and perpetuation of urban injustices. We seek to build on this work, but what distinguishes this article is that we work with two enduring critiques of the concept of urban informality to investigate the potential for improvements.

The first critique relates to the imprecision of the concept. Urban informality can be just about anything to anyone. An important source for this imprecision is traced back to the characterisation of the relationship between in/formality as a binary. As Rakowski (1994a) and Peattie (1987) note, the difficulties inherent in binaries have defined studies of informality since the beginning. In principle, the problems with binaries - that they rely on singularities, and are mutually exclusive and hierarchical - are well rehearsed, and we do not dwell on them here. In practice, however, they continue to drive research and urban policy that is out of kilter with the fact that most people think they live in a formal world (Benton, 1994: 225). Consequently, the concept seems blunt, imprecise and vague - consistently unable to grasp the intricacies of urban dynamics.

The second critique relates to the difficulties of applying the concept of urban informality to the well-established sites of Anglophone urban theory - the paradigmatic cities of 'the west'. 1 A well-established focus on how urban informality can/not work across many different countries has offered a productive vein of theoretical and practical insights (Robinson, 2006; Roy, 2005; Roy and AlSayyad, 2004; Song, 2016; Varley, 2013a; Watson, 2011). Through this work, and that of others, it is widely accepted that 'urban informality' has become a key way in which 'the urban' beyond 'the west' is known (Edensor and Jayne, 2012; Roy, 2012). Nevertheless, it is 
also clear that knowing the urban 'non-west' in this way ensures that any insights contribute to broader urban theories in particular, circumscribed ways (Roy, 2015). In short, what we know about 'the non-west' remains tethered to 'the west' in relationships that are generally not assumed to trouble the production of 'western' Anglophone urban theory (Chattopadhyay, 2012a). ${ }^{2}$ As a result, it is difficult to analyse urban informality as a constituent process of cities beyond the local of cities in the 'non-west' and to find a place for urban informality in broader urban theory.

We argue that these two critiques are related, as two aspects of the same problem, and that it is in examining the presence and operation of what we call common denominators, which hold these dichotomies together, that insights are yielded into ways of addressing this problem. Our view is that the emplacement of urban informality in urban theory is entangled with current ways of knowing 'the local' - insofar as 'the local' of urban informality is always limited by the persistent dualism between 'west'/"non-west'. Due to this double bind ('west'/'non-west' and 'urban theory'/development studies and similar), the discourse(s) on urban informality is (are) frustrated in achieving greater precision and wider contributions.

In addressing this double bind, we identify common denominators as pre-calibrated registers or mechanisms. These registers or mechanisms obscure sets of power relations in the background of debates, which currently foreground the well-known problems of working with the dichotomies outlined above. In identifying these mechanisms of common denominators, we address a weakness that has long plagued working with informality: that it 'offers a way of helping the poor without any major threat to the rich' (Bromley, 1978: 1036) because it leaves latent power relations untouched.
We commence by qualifying the context of our argument in order to locate our claims more precisely. We then proceed to characterise three different contemporary approaches urban informality as condition, laws and currency - to show how each has valuable characteristics, yet that, when considered as separate approaches, each in its own way contributes to the double bind. Working across the different approaches, we identify the operation of common denominators that animate Ann Varley's (2013b) insight to question how the difference within the binary pair of in/ formality is produced in practice rather than in principle. In this process, we recognise the immense value of existing approaches and propose to work across them; bringing them together in a distinctive way rather than discarding them. Through such means we hope to point to one way of disentangling the concept from its subordinated position in urban theory and improving its analytical precision in practice.

\section{Caveats}

In order to clarify the limits of our contribution, we locate our argument in relation to understandings of urban informality and urban theory, both of which are very contested. As a consequence, we need to be wary about identifying a singular historical trajectory of debate. Prior to the burgeoning interest in an 'urban informality' of cities in 'the non-west' that appears to bring together interests in both economic activities and housing (to cite the dominant historical strands), older perspectives had a slightly different emphasis. That is, early debates about informality were very much focused on informality in urban economies or in housing production systems rather than urban informality per se, that is, suggesting a particular urban quality to informality (Hart, 1973; Moser, 1994; Peattie, 1987; Rakowski, 1994b). ${ }^{3}$ It is useful to note that 
studies of economic informality have been more consistent in focusing on informality in typically 'western' countries than those that concentrate on the built environment and governance (Gërxhani, 2004; GuhaKhasnobis et al., 2007). This strand though has remained focused on relatively microeconomic issues and does not immediately appear to offer insights to a broader debate. We hazard a guess that this may well be to do with the qualities associated with 'urbanness' that concepts of urban informality try to develop, as we show in our discussion of common denominators below.

Added to this, seminal (Rakowski, 1994a) and recent sentinel contributions (Roy and AlSayyad, 2004; McFarlane and Waibel, 2012b) all offer different ways of thinking about urban informality. ${ }^{4}$ To repeat, the notion of 'urban informality' is relatively recent (AlSayyad, 2004). Despite the diversity, there seems to be a provisional consensus that urban informality relates to 'an organising urban logic ... [which] is a process of structuration that constitutes the rules of the game' (AlSayyad and Roy, 2004: 5). They go on to argue that this logic operates through the fixing and mapping of value/s, which have informed many other conceptualisations, including McFarlane and Waibel's (2012a). We use this as an initial entry point, but through considering the three different approaches, we try to reach towards something else.

A similar lack of agreement on what constitutes 'urban theory' and how this is produced (with a specific focus on who and where this production is located) adds another layer of difficulty. Inevitably, agreements on 'urban theory' are hard to find (Harding and Blokland, 2014) and current debates continue to unfold (see for example, Brenner and Schmid, 2015; Roy, 2015; Scott, 2017; Storper and Scott, 2016). It is also evident that where urban theory is produced has consequences for whether it counts as 'theory' or 'empirical evidence' of theory (Robinson, 2006). For the sake of focusing on our argument here, we work with 'urban theory' as a set of ideas, concepts and practices that relate to the urban as 'multiplex', as characterised by the dense overlapping multiple networks of times, spaces, networks and relations (Amin and Graham, 1997). In so doing, we are drawn to relational accounts of the urban that underpin trying to unravel how theorisations of the urban in 'the west' are tied to those in 'the non-west'.

\section{Knowing urban informality}

We review three contemporary approaches to the way in which urban scholars and policymakers know urban informality - informality as condition, laws and currency. Deploying 'knowing' as ways of both thinking and acting, our categories emerge from trying to make sense of our own work at the interface of theory, policy and practice. We know that reducing so many nuances to three approaches introduces many risks of simplification and misrepresentation. However, there is some value in presenting these approaches as emblematic of common assumptions. Our intention is not to characterise any one scholar's work cited here as solely falling into one categorisation, but merely to show that an insight they offer illustrates an aspect of a broader approach. What we point towards in this section is that, despite the rich insights of all three approaches, some of the imprecision relates to the consequences of how urban informality is conceptualised and that, individually, all three approaches find it difficult to challenge the emplacement in urban theory - that informality is predominantly something for understanding 'non-western' cities. Undoubtedly, our own categorisation will have its own limitations associated with ordering knowledge. 


\section{Informality as condition}

The first approach works principally by naming and categorising bounded entities as 'informal' to have powerful political effects. This set of analyses is recognisable in the labelling of spaces, people or organisations as 'informal'; the category of the informal is used as a descriptive qualifier for such 'conditions'. Thinking from informality as condition, policymakers, scholars and people 'living informally' can identify, and importantly describe, a condition of 'informality' according to a particular set of criteria. For example, a seminal ILO report mentions the following criteria to identify informal enterprises: whether they are registered or not, the number of employees, barriers to entry for that activity, and so on (ILO, 1972; Jhabvala et al., 2003). Similarly, in this approach it is presumed that settlements can be identified as 'formal' or 'informal' according to criteria such as the nature of property rights, levels of infrastructure, and services and planning, or forms of construction and types of construction of dwelling units (UN-Habitat, 2003, 2004). Indeed, the problem with these criteria is that they often lead to extended debates about their reliability and precision rather than how and why they apply. When the dichotomy is clearly overstated, which is particularly so when considering tenure security, some variations of this approach do try to introduce notions of a spectrum of informality (GLTN, 2012). These gradations are important and we will return to this issue when discussing common denominators below. For now, we point out that what tends to happen in this approach is that far fewer questions are asked about why the label is being applied in the first place.

Informality as condition is perhaps the most common way of thinking about urban informality. To situate this within other classifications in the debate, informality as condition resonates with the first three of the four conceptualisations identified by
McFarlane and Waibel (2012b): informality as spatial categorisation, organisational form and governmental tool. Examples abound and we would place most of our own work within this approach (see for example, Boano and Kelling, 2013; Marx, 2003, 2009). Other examples include Bayat's (1997: 10) slogan of the 'informal people' or expressions such as 'the informals' (Rakowski, 1994a: 3). Within the policy circuits of institutions focused on housing and land, such as UN-Habitat, the categorisation is ubiquitous and has served to inform many interventions by international agencies, NGOs and governments, and the movements of residents living in such parts of cities thought of as 'informal'.

Indeed, the strategic element of the labels 'formal'/'informal' for policy interventions is the main focus of the branch of research that McFarlane and Waibel (2012b: 4) have called informal-formal as a governmental tool'. These analyses focus on the technologies of categorisation, including mapping or statistics, as well as the ways in which they are applied (Elyachar, 2003). Amongst other possible interventions, a key enablement through labelling is seen to lie in that those entities which are tagged as 'informal' can easily be evicted and destroyed (Cabannes et al., 2010; Menon-Sen and Bhan, 2008).

Critical analyses of processes of using the label strategically for the purposes of legalisation and criminalisation have been highly influential in the field of urban and planning studies focused on 'the non-west'. One reason for this is that it allows scholars to understand informality as central to contemporary mechanisms of wealth distribution, and thus as a central means through which inequality is performed. It decouples informality from poverty, and affords an opportunity to recognise how powerful actors can deploy the mechanism of labelling to their advantage (Elyachar et al., 2005) whether this is by retrospectively legalising 
the constructions of wealthy urbanites or state agencies that are/were in breach of the law, or by delaying the moment of criminalisation of the constructs of the poor as long as their presence and proximity is useful (Roy, 2009; Yiftachel, 2009).

Indeed, it is here that the famous phrase of Roy finds its meaning: 'If formality operates through the fixing of value, including the mapping of spatial value, then informality operates through the constant negotiability of value' (AlSayyad and Roy, 2004: 5). In this sense, it is an 'organising logic' of governance, as referred to above in our initial definition. However, the view of informality as a mode of governance operates with a labelling logic itself. This is not only insofar as modes of governance are identified as either 'formal'/'informal' but also insofar as the condition of settlements as 'formal'/ 'informal' is conceptually accepted, even if it is understood as a category usually applied by the state. As a result, such critical analyses remain within the broader approach of informality as condition.

Despite its common-sense nature, it is interesting to reflect on what it means to work with informality as condition. That is, to be able to speak with, for or about people living or working in this assumed condition. The first reflection is that 'informality' becomes a state of being that has already been achieved. And, if the condition that is labelled informal is the result of prior social processes, they may no longer exist in the ever-changing space-times of cities and towns. Here, the emergence of informality can easily be reified and is read off from the current condition, creating the potential to misconstrue the dynamics of how the activities and spatial forms in question initially came into being.

We hazard a guess that for most scholars and practitioners the motivation for working with informality as a condition is captured within an impulse of a strand of subaltern studies. That is, to make 'visible and sayable' the conditions of life that obtain in such resource-poor urban environments (Roy, 2011). In a sense, it is to counteract the dominant tendency to consider what is conceptualised as 'informal economies' and/ or 'informal settlements' as invisible. Naming a condition allows activist-scholars to shed light on what this condition implies for those living 'in it' and, in the best cases, to empower them (Peattie, 1987). Thus, informality as condition offers a powerful way to make informality visible. It must do so in terms of formality but maybe that is not always a problem. There might be times when talking back to formality offers opportunities for meaningful change. In other instances, as Roy (2011) argues, there are limits to this strategy: thinking of informal settlements or economies as that which must be spoken for, we lose a sense in which that which is labelled informal cannot be understood through only what we know about it. For example, we lose an ability to know how it is constituted by relationality, processes and practices.

If urban informality is a (descriptive) condition then a key issue is: how and why do in/formality distinctions emerge? In our view, informality as condition must seek the emergence and origin of the condition elsewhere - typically in the practices of categorising by the state and/or planning, and, for some, there within neoliberalism. Thus, while often powerful in locating informality (of all types) in a universal logic of neoliberalism and in identifying the mechanisms of this labelling, this approach is less useful in analysing the actual social processes that context-specifically make up what comes to be identified - and identifiable - as 'urban informality'.

\section{Informality as laws}

A second dominant way in which urban in/ formality in 'non-western' cities is known 
draws on legal scholarship, particularly that strand associated with legal pluralism. From this perspective, urban informality in 'the non-west' is strongly related to laws and norms and is often finely nuanced (De Sousa Santos, 1977; Merry, 1988). In such situations, legal pluralism offers its own view on some of the mechanisms through which, for example, contested claims on urban property rights, and with them in/formality, are negotiated (Azuela de la Cueva, 1987; Fernandes and Varley, 1998). In short, legal pluralism holds that a plurality of legal systems coexists. In this work, it is recognised that there are many different 'sources' of law including state law, religious law, indigenous laws, customary laws and local conventions and norms that function as 'laws' (von Benda-Beckman, 2002). In such a legal pluralist view, state law is not necessarily always the dominant referent in the activities of people, and indeed, the state may not have the capacity to enforce state law (McAuslan, 2005). Moreover, such views also break an automatic link between state law and formality. From this perspective, customary law can be just as 'formal' as state law and state law can operate 'informally' (Benton, 1994: 225). They also break any automatic links between formality and regulation so that what counts as 'informal' in a given context can be just as regulated as that which counts as 'formal'.

This approach is rich in local empirical detail as it sets out to analyse how 'laws' or 'legal orders' - understood more capaciously - emerge, operate, are transformed and change from being considered 'formal' to 'informal' and vice versa. Such work starts out from what is conventionally taken as 'formal' or 'informal', with their respective bases in or outside of state law, but tries not to work with these as predetermined categorisations. Instead, it analyses how different legal systems co-exist and how this relates to the constitution of political authority. A key theme within such work focuses on tenure and property rights and how different tenures offer different levels of security for their users and holders - as well as expressing a range of other processes such as citizenship and economic development (McAuslan, 2003). The power relations between different legal systems are always central as each provides its particular set of rights and obligations (Chiodelli and Moroni, 2014). The informalisation of a specific 'legal order' of regulating property relations, for instance, usually means a significant shift in peoples' access to and control over resources.

This approach shows how taken-forgranted assumptions between laws, formality and regulation are flawed. Moreover, it highlights the link between informality, power and injustices. The focus on property rights is rarely picked up in other approaches, with notable exceptions being Roy (2003), Krueckeberg (1995, 2004) and Porter (2011). What it is less useful at doing is transcending the 'local' of the 'non-west' and thus contributing to broader urban theory. In its rich specificity of the 'local', there are echoes of labelling (and the associated issues) discussed above in relation to informality as condition. This is because it tends to work on the inherited positivist categorical assumption that the different legal systems that operate in a specific context are internally coherent and separate from each other (Melissaris, 2004). It is entire legal systems that are thought of as formal or informal.

\section{Informality as currency}

This approach primarily refers to contexts that might ordinarily be described as informal'. However, the research interest is not focused on that in/formality but on the activities of residents of cities that are essential for the way in which the cities work, and on an understanding of why the residents follow 
these activities (Guyer, 2011). In short, it is an interest in the social and spatial organisation of how people make the city (De Boeck and Plissart, 2004). We call this way of knowing 'informality as currency' because it acknowledges that actors in the field consider some activities, people or spaces as 'informal', and that this consideration has a meaningful social effect - it has a sociopolitical 'currency' that can be mobilised. Thus, informality as currency approaches the topic with sufficient nuance to understand the social effect of how we (as in, everyone) recognise and interpret our practices and those of others - without buying into these interpretations (Guibrunet, 2017).

In contrast to that approach of informality as condition, which works with 'informalformal as a governmental tool', the label is understood as more than a tool of the state for enabling desired interventions; it is understood as one of multiple factors structuring the social and spatial organisation of the city (Meagher, 2010). In informality as currency, the term has currency for/in how residents, other scholars and policymakers know a given city and cities in general and is not taken as a reason to define these or any other activities, people or spaces as essentially informal.

This way of knowing informality, and indeed of doing urban research more generally, presents a rich analysis of the construction of social relations and their spatiality, and offers a complementary perspective to the previous two approaches. Informality as currency suggests that many other issues are more relevant to people's lives than state law and policy categorisations. Even if the categories of formality and informality have spread wide and gained a firm foothold in the reflexive understanding of the world of many people in the 'non-west', it is not the only framing through which people understand their lives, and may indeed often be of peripheral importance (Chattopadhyay, 2012b). Here, we are firmly into a relational perspective that emphasises flux and changes, while still recognising regularity.

The basis for this view is drawn from long standing sociological insights and is usefully captured by Tonkiss (2013: 93): ‘... informality is something of a non-concept. A lack of legal "formality" does not mean either an absence of form or a lack of organization'. In contrast to informality as laws, this perspective acknowledges that practices are socially organised - whether by formal or informal norms/rules/routines. The idea of organisation is different from the broad conception of 'laws' of informality as laws, which, even if extending beyond state law, still refers to codified sets of legal rules, whether set by a religious, customary or any other authority. Instead of seeing one legal system as informal and the other as formal, informality as currency is able to recognise that some ways of doing things have been codified into a legal rule with formal status, and others have not - within the same context of social organisation. Indeed, the crucial novelty of informality as currency is its implicit ability to see the element of active social organisation in those practices and activities that are ordinarily understood as 'informal', but that within the other perspectives are conventionally and more passively considered as spontaneous and unorganised.

Informed by the view that, by nature, humans need some form of regularity and stability in their social fields of interaction, Simone (2004, 2006, 2012), for instance, argues for a need to move away from searching for large institutional sedimentations, based on bounded categories that are characteristic of the era of nation-states. Instead, in precarious living situations people find regularity in provisionality through an open attitude towards collaborative practice with others, through the ability to become easily familiar with new arrangements (Simone, 2001, 2004). In this approach, the focus falls 
on analysing the dynamics that are active in assumedly formal and predictable institutions (Kudva, 2009), and on recognising the regularities in that which scholars have come to know as informal - and which we concomitantly think of as rather fluid and volatile.

Informality as currency is useful for showing how informality is constituted from a range of practices, categorisations and places. It starts to demonstrate how many of the informal activities are composed of relations that extend well beyond the 'local' and ties places together in ways that are not anticipated by urban theory (Simone, 2003). While the focus remains on the 'local', it is powerful at detailing how cross-scalar relations emerge and constitute the local. Through this, it offers more purchase on, and substance to, local dynamics rather than just assuming that these relations are those of neoliberal impulses. Overall, informality as currency is closer to contemporary urban theory and folds the notion of the informal into it. However, it still remains within the regional dualism of 'the west' and 'the nonwest' currently due its choice of case studies, and its (legitimate) priority of conceptualising 'the urban' rather than informality itself.

\section{Discussion}

In this section, we reach towards a different understanding to address the double bind of the concept of urban informality of firstly lacking precision and secondly contributing to broader urban theory in circumscribed ways. That is, while all of the three approaches offer their own specific insights on the 'local'; all three are also constrained in contributing to a broader urban theory. None of the three approaches really challenge the emplacement of urban informality, although they all, in one way or another, seek to do so. We suggest that working with common denominators of urban informality, it is possible to simultaneously do (at least) two things in order to start disentangling the double bind: 1) provide a more precise grasp of what is going on locally, and 2) address the structural inequalities in urban theories. In doing this, scholars may finally come up with an understanding of urban informality that can 'trouble the rich'.

We propose a way of addressing this double bind that may animate Ann Varley's (2013b) advice to work with 'difference in practice rather than in principle'. This means that instead of sustaining an initial assumption that a bounded entity like a settlement is informal or formal, we should focus on a more relational approach (Boudreau and Davis, 2017) and the practices that make it possible to think of these bounded entities in terms of being in/formal. This, we argue, offers the possibilities of being attentive to a wider set of power relations and of escaping the double bind that besets the current usage of the concept. In principle, many of these practices are well-documented by wellestablished critiques of binary thinking - that binaries rely on singularities, are mutually exclusive and hierarchical - and these critiques are well-rehearsed in the urban informality debate and across our three approaches. In practice, however, we have identified through the review that the distinction between the formal and the informal as a binary is sustained by implicit common assumptions that hold the pair together. We call this a common denominator.

Common denominators are specific registers or mechanisms which, without being addressed explicitly, allow scholars or policymakers, or anyone else, to name two entities as a coherent binary pair that 'makes sense'. For example, 'informal settlement' makes sense in opposition to 'formal settlement' because it is held together by assumptions about, for instance, property rights. It makes little sense as an opposition to 'refugee settlement', for example. In the following, we illustrate this idea by elaborating on 
two common denominators - property rights systems and urban aesthetics. These examples are indicative and suggestive. Others are likely to exist and wait to be explored. Before illustrating these two, though, we make a few more general statements about common denominators and how they work to stabilise latent power relations.

We identify three aspects to how common denominators practically facilitate the construction of the binary formal/informal. The first aspect to note - drawing from informality as currency - is that people actively construct the binary oppositions of in/formality. However, there are two points to make about these constructions. First, if these constructions are to 'make sense' they must tend towards the well-worn tracks of existing constructions. Second, although people are in multiple relationships with others, these multiple relations present different affordances to exercise (naming) agency around informality. Both the existing constructions and the differing abilities to escape the existing constructions are already the result of unequal power relations. Therefore, analysing how people are constructing binary oppositions to 'make sense' and who is able to do/contest this should provide insights into what contexts, activities and understandings support current (unequal) framings of urban informality.

The second aspect to note about how common denominators work is that they conceal latent power relations by appearing so obvious. The calibrations within the common denominator dovetail with existing binary distinctions, making the binaries seem natural. What is key here is that the 'fit' between common denominators and binary distinctions is only 'natural' because the common denominator is itself already reflective of binary distinctions and gradations between these. This makes it extremely difficult to challenge the binary distinctions and also to challenge how the common denominator is operating. This observation is even more troubling when accounting for the ways that common denominators tend to be expressions of (existing) power relations.

The third aspect is that common denominators must appear to be kept stable and coherent to allow movement within the binary pairing; that is, either through granting interventions with the potential of 'closing the gap' between the opposites (through mixing or hybridising) or through promoting the transformation of one into the other (typically converting the 'informal' into the 'formal') - for better or worse. These movements cannot be promoted and measured if the yard stick represented in the common denominator is itself moving. This means that scholars and policymakers aiming for such transformation are implicitly encouraged to accept the (predetermined) coherence of common denominators with their already existing power relations at play. Seen in combination, these three aspects are suggestive of the latent power of common denominators at work.

We demonstrate the latent working of common denominators with the example of property rights. These are frequently used as a common denominator in analyses of in/ formal settlements within cities in 'the nonwest'. One of the most common associations with property rights is land values. This particular association is made in practice despite the multiple options that exist to relate property rights to different legal systems, histories, gender relations and so on. It is also evident that gradations of security of tenure (informal, semi-informal, formal) correspond in predetermined ways to the binary distinctions between in/formality (GLTN, 2010) that serve to 'naturally' reinforce the self-evident nature of the binaries. Urban property rights (and their associated markets; see for example, Wallace and Williamson (2006)) are also generally considered to be evolving through specific 
gradations towards clearer forms of private property (Fitzpatrick, 2006). In this technomarket understanding, deviations from this evolution (such as persistent informality) are considered anomalies that need to be corrected but the gradations themselves are rarely questioned.

Thus, using this view of property rights as a common denominator unintentionally already locks in assumptions about where on the spectrum an asset or practice fits, what value it has and which registers of value count, how they should change and who can legitimately participate in naming any changes. More importantly, these assumptions remain unexamined because the focus of debate falls on challenging the power relations that are associated with binaries themselves (for instance, implied hierarchies). In effect, such debates about informality are rarely a 'threat to the rich' insofar as the unquestioned common denominator confirms that the assets of the rich are on the 'safe' (i.e. formal) side of the binary.

In a similar way, we now explore how theorisations of informality in cities in 'the non-west' rarely trouble the formulation of broader urban theory emerging from cities in 'the west'. Here we take another example of a frequently used common denominator that of urban aesthetics. Ghertner (2015) has deployed the concept to great effect within Delhi to reveal how power relations inhere in an aesthetic register of urban governance. Now, we demonstrate how this might apply across a 'west - non-west' binary within urban theory. At a very obvious level, the point is often made that analyses of urban informality have little relevance for 'western' cities because we just do not have it in the urban form and quality of urban spaces produced in these cities. The debate begins and ends on the presence of urban spaces of informality in 'non-western' cities, and their absence or at best marginal and exceptional presence in 'western' cities.
In order to address this marginality in 'western' cities, scholars have pointed to informalities of different kinds; for example, the 'informality of the rich' (Tonkiss, 2013: 94-95); the association of migrants with informality, that is, informality being brought to 'the west' from elsewhere (see the discussion of Durst and Wegmann (2017)); or the phenomena of 'pop-up urbanism' and 'do-it-yourself urbanism' (Tonkiss, 2013), which have little to do with the severity of inadequate provisioning of urban goods. As before, attending to the operation of the common denominators reveals a series of power relations that inhere in common assumptions, and that have the effect of making it difficult to question the emplacement of 'non-western' ways of knowing informality in broader urban theory. At the core of the aesthetic register are urban imaginations and their reproduction through the spatiality of poverty.

One aspect is how informality is associated with a particular scale of agglomeration so that the (relatively) dispersed backyard sheds offering accommodation in London cannot be related to the backyard shacks offering accommodation in cities like Johannesburg. A second is how poverty is assumed to be part of informality so that poverty and informality work together. But, only certain types of poverty - the kind that is found in 'non-western' cities. 'Western' cities with extensive poverty, such as London (Child Poverty Action Group, 2017), are not considered to relate to urban informality. Implicitly, the two aspects above are seen as reasons not to relate a city like London to urban informality; yet it remains overlooked that the dominant aesthetic register that makes the 'slum' the metonym of the developing world (Roy, 2011) may be the reason why housing deprivation develops in such non-recognisable / non-slum forms in the first place. Following Dovey and King's (2011) observation in Asia, these 'invisible forms' may be the only forms 
that responses to urban need can take on they are a product of the aesthetic register and they reproduce it.

The relevance of the aesthetics of the 'slum' in the constitution of the difference between 'the west' and 'the non-west' appears established. Not for discussion is how this register of urban imaginations is also structuring possibilities of recognising and speaking of urban informality itself.

\section{Conclusion}

We have argued that two of the enduring critiques of urban informality, that first it lacks enough precision in studying events, relations and processes in place, and second that it is circumscribed in contributing to broader urban theory, are two aspects of the same problem - an inability to recognise and account for the effects of common denominators. It is only by working across the three approaches that we can show how the common denominators emerge in the practices of constituting urban informality.

In relation to improving the analytical precision at a city level, we drew on the example of property rights as a common denominator. We showed that if the common denominator is questioned, then scholars gain an ability to question an important aspect of the power relations that hold binaries together. For example, we gain an ability to question why it is that distinctions between in/formal property rights are automatically discussed in terms of land values. We are afforded an opportunity to question how calibrated distinctions in property rights already incorporate binary distinctions between in/formality. And, we gain an ability to question why challenging calibrations of property rights must be thought through the stages identified in evolutionary theories of property rights (which themselves reinforce specific notions of land value). Overall, we gain an ability to identify the latent power relations that already inhere in these specific understandings of land value, predetermined calibrations and changes that are already set out as logical. Attending to the practices, spaces, processes and agents and the inequalities that inhere or which are performed through them offers the potential to be more analytically precise about what constitutes urban informality and how such understandings are sustained. It helps us analyse the ways that urban informality emerges and is sustained, and the effects it has.

With respect to the emplacement of urban informality in contributing to broader urban theory, the common denominator of urban aesthetics affords possibilities to question why it is that scholars are actively only able to discuss urban informality in cities in 'the west' in terms of the lack of scale of the phenomenon. It offers the chance to question how understandings of poverty already dovetail with notions of urban informality. It also affords questions about the reproduction of the aesthetic register itself through the spatiality of poverty. Attending to these questions enables us to question the processes and assumptions that currently emplace urban informality as primarily a 'non-western' city phenomenon.

The examples of common denominators explored here are indicative and suggestive. It is clear that there will be many more to identify and challenge and that we could similarly think how an aesthetic common denominator could be operating within cities and a common denominator of property rights could be operating between cities in relation to urban theory. What they draw our attention to is their necessarily relational character and ways in which they must continually be achieved in practice. Herein lies the potential to hold open the possibilities to develop notions of urban informality that can more precisely identify and challenge the latent power relations that remain 
unquestioned in analysing urban inequalities within cities and distinctions across urban theories.

\section{Acknowledgements}

The authors are extremely grateful to the Editors, referees and Guest Editors of the special issue, for extensive and insightful comments. We also thank Vanesa Castàn-Broto for valuable comments on our first submission. Any errors remain ours alone.

\section{Declaration of conflicting interests}

The author(s) declared no potential conflicts of interest with respect to the research, authorship, and/or publication of this article.

\section{Funding}

The author(s) received no financial support for the research, authorship, and/or publication of this article.

\section{ORCID iD}

Colin Marx (iDhttps://orcid.org/0000-0001-85020390

\section{Note}

1. In line with Robinson's (2002) argument that such categories misconstrue our understanding of the world, we refer to them only insofar as their currency is directly linked to our argument about informality. We use 'west' and 'non-west' (with the quotation marks indicating our distance) instead of south-north or developingdeveloped because the pedestal of 'western' urban theory is the most troubling element of our critique. While using these categories runs the risk of reproducing them, we have no alternative when addressing their implications as a core problem of our argument.

2. In this article, we concentrate on Anglophone urban theory as the focus of the article and as a recognition of the positional limitations of our argument in relation to other canons of urban scholarship.
3. An important early distinction between 'structuralist' and 'legalist' analyses of informality can be conceived of as typically applying analysis of informality to 'the urban' (see Rakowski, 1994a).

4. It is interesting that Laguerre's (1994) outstanding analyses of informal San Francisco in The Informal City have had relatively little impact on the debate of urban informality.

\section{References}

AlSayyad N (2004) Urban informality as a "new" way of life. In: Roy A and AlSayyad N (eds) Urban Informality: Transnational Perspectives from the Middle East, Latin America, and South Asia. Oxford: Lexington Books, pp. 7-30.

AlSayyad N and Roy A (2004) Prologue/dialogue. Urban informality: Crossing borders. In: Roy A and AlSayyad N (eds) Urban Informality: Transnational Perspectives from the Middle East, Latin America, and South Asia. Oxford: Lexington Books, pp. 1-6.

Amin A and Graham S (1997) The ordinary city. Transactions of the Institute of British Geographers 22: 411-429.

Azuela de la Cueva A (1987) Low income settlement and the law in Mexico City. International Journal of Urban and Regional Research 11(4): 522-541.

Bayat A (1997) Un-civil society: The politics of the "informal people". Third World Quarterly 18(1): 53-72.

Benton LA (1994) Beyond legal pluralism: Towards a new approach to law in the informal sector. Social and Legal Studies 3(2): 223-242.

Boano C and Kelling E (2013) Toward an architecture of dissensus: Participatory urbanism in South-East Asia. Footprint 13: 41-62.

Boudreau J-A and Davis DE (2017) Introduction: A processual approach to informalization. Current Sociology 65(2): 151-166.

Brenner N and Schmid C (2015) Towards a new epistemology of the urban? City 19(2-3): 151-182.

Bromley R (1978) Introduction - The urban informal sector: Why is it worth discussing? World Development 6(9-10): 1033-1039. 
Cabannes Y, Guimarães Yafai S and Johnson C (2010) How the Poor Face Evictions. London: Development Planning Unit, UCL.

Chattopadhyay S (2012a) Urbanism, colonialism and subalternity. In: Edensor T and Jayne M (eds) Urban Theory Beyond the West. Abingdon: Routledge, pp. 75-92.

Chattopadhyay S (2012b) Unlearning the City: Infrastructure in a New Optical Field. Minneapolis, MN: University of Minnesota Press.

Child Poverty Action Group (CPAG) (2017) Poverty: The Facts. London: CPAG.

Chiodelli F and Moroni S (2014) The complex nexus between informality and the law: Reconsidering unauthorised settlements in light of the concept of nomotropism. Geoforum 51: 161-168.

De Boeck F and Plissart MF (2004) Kinshasa: Tales of the Invisible City. Amsterdam: Ludion.

De Sousa Santos B (1977) The law of the oppressed: The construction and reproduction of legality in Pasargada. Law and Society Review 12(1): 5-126.

Dovey K (2012) Informal urbanism and complex adaptive assemblage. International Development Planning Review 34(4): 349-368.

Dovey K and King R (2011) Forms of informality: Morphology and visibility of informal settlements. Built Environment 37(1): 11-29.

Durst NJ and Wegmann J (2017) Informal housing in the United States. International Journal of Urban and Regional Research 41(2): 282-297.

Edensor T and Jayne M (eds) (2012) Urban Theory Beyond the West: A World of Cities. Abingdon: Routledge.

Elyachar J (2003) Mappings of power: The state, NGOs, and international organisations in the informal economy of Cairo. Comparative Studies in Society and History 45(3): 571-605.

Elyachar J, Steinmetz G and Adams J (2005) Markets of Dispossession: NGOs, Economic Development and the State in Cairo. Durham, NC: Duke University Press.

Fernandes E and Varley A (1998) Law, the city and citizenship in developing countries: An introduction. In: Fernandes E and Varley A (eds) Illegal Cities: Law and Urban Change in Developing Countries. London: Zed Books, pp. 3-17.

Fitzpatrick D (2006) Evolution and chaos in property rights systems: The Third World tragedy of contested access. The Yale Law Journal 115(5): 996-1048.

Gërxhani K (2004) The informal sector in developed and less developed countries: A literature survey. Public Choice 120: 267-300.

Ghertner DA (2015) Rule by Aesthetics: WorldClass City Making in Delhi. New York: Oxford University Press.

Global Land Tools Network (GLTN) (2010) Count Me In: Surveying for Tenure Security and Urban Land Management. Nairobi: UNHabitat.

Global Land Tools Network (GLTN) (2012) Handling Land: Innovative Tools for Land Governance and Secure Tenure. Nairobi: UN-Habitat, Global Land Tools Network and IIRR.

Guha-Khasnobis B, Kanbur R and Ostrom E (2007) Linking the Formal and Informal Economy: Concepts and Issues. UNU-Wider Studies in Development Economics. Oxford: Oxford University Press.

Guibrunet L (2017) The contribution of the informal economy to urban sustainability: Case study of waste management in Tepito, Mexico City. $\mathrm{PhD}$ thesis, University College London, UK.

Guyer JI (2011) Describing urban 'no man's land' in Africa. Africa 81(3): 474-492.

Harding A and Blokland T (2014) Urban Theory: A Critical Introduction to Power, Cities and Urbanism in the 21st Century. London: SAGE Publications.

Hart K (1973) Informal income opportunities and urban employment in Ghana. Journal of Modern African Studies 11(1): 61-89.

International Labour Organisation (ILO) (1972) Employment, income and equality: A strategy for increasing productivity in Kenya. Geneva: ILO.

Jhabvala R, Sudarshan RM and Unni J (2003) Informal Economy Centrestage: New Structures of Employment. New Delhi: SAGE Publications Pvt. Ltd.

Krueckeberg D (1995) The difficult character of property. Journal of the American Planning Association 61(3): 301-309.

Krueckeberg DA (2004) The lessons of John Locke or Hernando de Soto: What if your dreams come true? Housing Policy Debate 15(1): 1-24. 
Kudva N (2009) The everyday and the episodic: The spatial and political impacts of urban informality. Environment \& Planning A 41(7): 1614-1629.

Laguerre MS (1994) The Informal City. New York: Palgrave Macmillan.

McAuslan P (2003) Bringing the Law Back In: Essays in Land, Law and Development. Aldershot: Ashgate.

McAuslan P (2005) Legal pluralism as a policy option: Is it desirable, is it doable? Paper presented at UNDP-International Land Coalition Workshop: Land Rights for African Development: From Knowledge to Action, Nairobi, 31 October-3 November 2005.

McFarlane C (2012) Rethinking informality: Politics, crisis, and the city. Planning Theory and Practice 13(1): 89-108.

McFarlane C and Waibel M (eds) (2012a) Urban Informalities: Reflections on the Formal and Informal. London: Routledge.

McFarlane C and Waibel M (2012b) Introduction: The informal-formal divide in context. In: McFarlane $\mathrm{C}$ and Waibel $\mathrm{M}$ (eds) Urban Informalities: Reflections on the Formal and Informal. London: Routledge, pp. 1-12.

Marx C (2003) Supporting informal settlements. In: Khan F and Thring P (eds) Housing Policy and Practice in Post-Apartheid South Africa. Sandown: Heinemann, pp. 299-320.

Marx C (2009) Conceptualising the potential of informal land markets to reduce poverty. International Development Planning Review 31(4): 335-353.

Meagher K (2010) The tangled web of associational life: Urban governance and the politics of popular livelihoods in Nigeria. Urban Forum 21(3): 299-313.

Melissaris E (2004) The more the merrier? A new take on legal pluralism. Social \& Legal Studies 13(1): 57-79.

Menon-Sen K and Bhan G (2008) Swept off the Map: Surviving Eviction and Resettlement in Delhi. New Delhi: Yoda Press.

Merry SE (1988) Legal pluralism. Law \& Society Review 22(5): 869-896.

Moser CON (1994) The informal sector debate, Part 1: 1970-1983. In: Rakowski CA (ed.) Contrapunto: The Informal Sector Debate in
Latin America. Albany, NY: State University of New York Press, pp. 11-29.

Peattie L (1987) An idea in good currency and how it grew: The informal sector. World Development 15(7): 851-860.

Porter L (2011) Informality, the commons and the paradoxes for planning: Concepts and debates for informality and planning. Planning Theory \& Practice 12(1): 115-153.

Rakowski C (1994a) Contrapunto: The Informal Sector Debate in Latin America. Albany, NY: State University of New York Press.

Rakowski C (1994b) The informal sector debate, Part 2: 1984-1993. In: Rakowski CA (ed.) Contrapunto: The Informal Sector Debate in Latin America. Albany, NY: State University of New York Press, pp. 31-50.

Robinson J (2002) Global and world cities: A view from off the map. International Journal of Urban and Regional Research 26(3): 531-554.

Robinson J (2006) Ordinary Cities. London: Routledge.

Roy A (2003) Paradigms of propertied citizenship: Transnational techniques of analysis. Urban Affairs Review 38(4): 463-491.

Roy A (2005) Urban informality: Towards an epistemology of planning. Journal of the American Planning Association 71(2): 147-158.

Roy A (2009) Strangely familiar: Planning and the worlds of insurgence and informality. Planning Theory 8(1): 7-11.

Roy A (2011) Slumdog cities: Rethinking subaltern urbanism. International Journal of Urban and Regional Research 35(2): 223-238.

Roy A (2012) Urban informality: The production of space and practice of planning. In: Crane $\mathrm{R}$ and Weber R (eds) The Oxford Handbook of Urban Planning. Abingdon: Oxford University Press [Oxford Handbooks Online], pp. 1-18. DOI: 10.1093/oxfordhb/9780195374995.013.0033.

Roy A (2015) Who's afraid of postcolonial theory? International Journal of Urban and Regional Research 40(1): 200-209.

Roy A and AlSayyad N (2004) Urban Informality: Transnational Perspectives from the Middle East, Latin America, and South Asia. Oxford: Lexington Books.

Schindler S (2014) Producing and contesting the formal/informal divide: Regulating street 
hawking in Delhi, India. Urban Studies 51(12): 2596-2612.

Schindler S (2017) Beyond a state-centric approach to urban informality: Interactions between Delhi's middle class and the informal service sector. Current Sociology 65(2): 248-259.

Scott AJ (2017) The Constitution of the City. Cham: Palgrave Macmillan. Available at: https://link.springer.com/book/10.1007\% 2F978-3-319-61228-7.

Simone A (2001) Straddling the divides: Remaking associational life in the informal African city. International Journal of Urban and Regional Research 25(1): 102-117.

Simone A (2003) Reaching the larger world: New forms of social collaboration in Pikine, Senegal. Africa 73(2): 226-250.

Simone (2004) People as infrastructure: Intersecting fragments in Johannesburg. Public Culture 16(3): 407-429.

Simone A (2006) Pirate towns: Reworking social and symbolic infrastructures in Johannesburg and Douala. Urban Studies 43(2): 357-370.

Simone A (2012) Screen. In: Lury C and Wakeford $\mathrm{N}$ (eds) Inventive Methods: The Happening of the Social. Abingdon: Routledge, pp. 202-218.

Song LK (2016) Planning with urban informality: A case for inclusion, co-production and reiteration. International Development Planning Review 38(4): 359-381.
Storper M and Scott AJ (2016) Current debates in urban theory: A critical assessment. Urban Studies 53(6): 1114-1136.

Tonkiss F (2013) Cities by Design: The Social Life of Urban Form. Cambridge: Polity Press.

UN-Habitat (2003) The Challenge of Slums: Global Report on Human Settlements. London: Earthscan Publications.

UN-Habitat (2004) Pro Poor Land Management: Integrating Slums into City Planning Approaches. Nairobi: UN-Habitat.

Varley A (2013a) Postcolonialising informality? Environment \& Planning D: Society and Space 31(1): 4-22.

Varley A (2013b) Feminist perspectives on urban poverty: De-essentialising difference. In: Peake $\mathrm{L}$ and Rieker M (eds) Rethinking Feminist Interventions into the Urban. Abingdon: Routledge, pp. 125-141.

von Benda-Beckman F (2002) Who's afraid of legal pluralism? Journal of Legal Pluralism 47: $37-82$.

Wallace $\mathbf{J}$ and Williamson I (2006) Building land markets. Land Use Poicy 23(2): 123-135.

Watson V (2011) Engaging with citizenship and urban struggle through an informality lens. Planning Theory \& Practice 12(1): 150-153.

Yiftachel O (2009) Theoretical notes on 'gray cities': The coming of urban apartheid? Planning Theory 8(1): 88-100. 